\title{
Viewing Climate Change Impact through Maize Varietal Sowing at Variant Intervals
}

\author{
Shabir Muhammad ${ }^{1 *}$, Ishaq Ahmad Mian ${ }^{1}$ and Muhammad Fawad ${ }^{2}$ \\ ${ }^{1}$ Department of Soil and Environmental Sciences, The University of Agriculture Peshawar, Pakistan \\ ${ }^{2}$ Department of Weed Science, The University of Agriculture Peshawar, Pakistan
}

${ }^{*}$ Corresponding author: Shabir Muhammad, Department of Soil and Environmental Sciences, The University of Agriculture Peshawar, Pakistan, Email: shabir@aup.edu.pk

Received Date: March 03, 2019; Accepted Date: March 13, 2019; Published Date: April 25, 2019

Copyright: (c) 2019 Muhammad S, et al. This is an open-access article distributed under the terms of the Creative Commons Attribution License, which permits unrestricted use, distribution, and reproduction in any medium, provided the original author and source are credited.

Citation: Muhammad S, Mian Al, Fawad M (2019) viewing climate change impact through maize varietal sowing at variant intervals. Eur Exp Biol Vol.9 No. 1:3

\section{Abstract}

Climate change is one of the detrimental factors for plant growth. A change in temperature can lead to a high loss in crop productivity. Keeping the detrimental effect of climate change on plant growth and productivity, research was carried out to mitigate the climate effect on crop productivity. Ten maize hybrids and varieties were selected for the experiment and were sown on five different sowing times. The experimental analysis was carried out in Randomized Complete Block Design with split plots arrangement having three replications. Sowing times were allocated to main plots while varieties and hybrids were allotted to the subplots, respectively. The results revealed that different varieties and hybrid shows a different response to variant sowing times. Maximum plant height was recorded by SB-989, maximum biological yield was recorded by Azam variety while maximum grain yield was recorded by SB-909 hybrid maize cultivar. Similarly early sowing time $5^{\text {th }}$ June showed better results in terms of plant height, grain yield and biological yield. From the results, it was concluded that maize variety showed by sown on 5 th June to attain maximum output in terms of yield and yield attributes.

Keywords: Sowing times; Varieties; Hybrids; Maize; Climate change

\section{Introduction}

Maize (Zea mays L.) is known to be the most important cereal crop after wheat and rice. Mostly grown well in temperate, tropical and sub-tropical regions. It is used for multipurpose for example as a food for humans, feed for animals and as a raw material for industries. In terms of total production and yield per unit area maize is the leading cereal of the world with total production of 695 tons and $4815 \mathrm{~kg}$ yield ha-1 [1-8]. It is used as a raw material in the starch industry for the preparation of many products. In Pakistan, in 2009 maize average production is $\mathbf{3 8 0 5}$ $\mathrm{kg} \mathrm{ha}^{-1}$ while in Khyber Pakhtunkhwa the average production of maize is $1751 \mathrm{~kg} \mathrm{ha}^{-1}$ which is more than $50 \%$ less from the average production of Pakistan. Maize is used in industries for the preparation of corn oil, corn sugar, corn protein, corn flacks and corn syrup [9].

Climate is known to be the average weather condition of an area whereas some changes or variations in the average weather condition is climate change. Main causes for climate change is pollutants release to the environment by living entities (Biotic), volcanic eruptions, imbalanced solar radiations received on the earth surface and tectonic plates. Production of the crop is targeted differently by climate change in different areas of the world. In some places, it causes enhancement in crop productivity while mostly results in reduction [10-18]. In sustainable farming, organic manure is the most common fertilizer used in the developing countries [19-31]. For sustainable growth, the most important step is the selection of the best variety for production [9]. Sowing date impact on crop is as much important as that of selection of variety for sustaining productivity under the scenario of climate change mostly high summer temperature effect anthesis in some areas of Pakistan [3]. A particular sowing date is very important for optimum production with respect to regional climate change [18]. Fixed sowing time is important for such a regional climate change [9]. Due to high seasonal temperature effect on seeds, time of pollination, grain filling and moisture fluctuation of field productivity incomes are also changing the productivity of maize crop $[10,11]$. Soil fertility and water availability should be the prime factors for the farmers locally or non-local [3]. However, planting date response depending on weather variability at a given location, also differ to a great deal among the years and locations etc. The present study was initiated to investigate the performance of maize varieties when sown in different time for yield and yield contributing traits under the agro-climatic condition of Pakistan [17]. 


\section{Materials and Methods}

\section{Description of the study area}

The field experiment was conducted at Mohmand Agency Ghazi Beg Kaly (FATA, Federal Administrated Tribal Area). The site was selected on the main road about 5 kilometres away from Ghalanai, Agency headquarter. The physic-chemical properties of the site are given in Table 1 . It lies between $34^{\circ} 10^{\prime}$ to $34^{\circ} 43^{\prime}$ north latitudes and $70^{\circ} 58^{\prime}$ to $71^{\circ} 42^{\prime}$ east longitudes. The climate in Mohmand agency is hot in the summer season while cool in winter. The summer season commences from May and continues for 4 months till $31^{\text {st }}$ August [20-22]. The winter season starts from November and continues till February. The rainfall is scanty. Most of the rainfall is during the winter season. The main agricultural areas in the valleys of Mohmand receive about $100 \mathrm{~mm}$ of average rainfall per annum.

\section{Soil samples collection}

A total of 6 soil samples were collected at a depth of $0-15 \mathrm{~cm}$ with the help of soil auger from Mohmand Agency Ghazi Beg Kaly FATA, from each subplot. Each sample was then labelled indicating the location from where the samples were collected. Samples were then transported to the laboratory of Soil and Environmental science Depart. University of Agriculture Peshawar [26-28].

\section{Field experimental design}

A Randomized Complete Block Design (RCBD) with split plot arrangement having three replications was used. Factor- $A$ (Sowing Dates) was in main plots while Factor-B (Varieties) was in the subplots $[29,30]$. The main focus of the research was to study the effect of sowing time on different varieties of the maize crop. Detail of treatments is as follows.

\section{Field preparation}

The total size of the research field was $2400 \mathrm{~m} 2(60 \mathrm{~m} \times 40$ $\mathrm{m})$. As per the desired layout, the field was divided into 50 small experimental units with $24 \mathrm{~m}^{2}(6 \mathrm{~m} \times 4 \mathrm{~m})$ each. The tillage was done by tractor to improve its physical properties like increasing soil aeration and improvement of water infiltration [32-35]. The soil was ploughed with chisel plow to cut soil then used the disc plow to invert the soil. Tillage was used to cut the remaining residues of the previous crop and to break the soil clods and pulverize the soil. At the end, planking was done to level the field [36]. After the completion of tillage operations, a complete layout was marked to separate the area for different sowing methods, water channels and borders [37].

Factor-A: SD1; SD2; SD3; SD4; SD5

Sowing dates for Factor A: 1 June 2015; 10 June 2015; 22 June 2015; 3 July 2015; 13 July 2015

Factor-B: V1; V2; V3; V4; V5; V6; V7; V8; V9; V10

Varieties for Factor B: CS-220; CS-200; SB-989; IQBAL; W-888; JALAL; SB-909; AZAM; BABAR; SB-292

\section{Data was recorded for the following parameter}

1. Plant height $(\mathrm{cm})$

2. Biological yield $\left(\mathrm{kg} \mathrm{ha}^{-1}\right)$

3. Grain yield $\left(\mathrm{kg} \mathrm{ha}^{-1}\right)$

\section{Agronomic data}

The following agronomic data were collected.

\section{Plant height $(\mathrm{cm})$}

At physiological maturity, plant heights were recorded for each subplot by randomly measuring 20 selected plants from the base of the plant to the tip of tassel and average was recorded [38].

\section{Fresh biomass (kg ha-1)}

Three rows were harvested and the fresh biomass including the cobs was weight and the data were converted to $\mathrm{kg}$ ha-1[39].

\section{Grain yield $\left(\mathrm{kg} \mathrm{ha}^{-1}\right)$}

Three rows were harvested and cobs were weight. For moisture content, three cobs randomly selected in 20 plants then dry the cobs in sunlight and then remove the grains from sheets, and weighted with digital balance then convert the gram weight of grains into grain yield $\left(\mathrm{kg} \mathrm{ha}^{-1}\right)$ through the following formula [40]. The moisture content was deducted from the fresh grain weight.

$$
\text { Grain yield }=\frac{\text { Grain yield per three rows }}{\text { No. of rows } \times \text { row length } \times R-R \text { distance }} \times 10000
$$

\section{Results and Discussion}

Soils of the area are generally medium textured to clay-loam and are low in natural fertility, Nitrogen, organic matter and Phosphorus are deficient. The soils are having a $\mathrm{pH}$ of 7.5 to 8.5.

\section{Plant height $(\mathrm{cm})$}

Data presented in (Table 2) showed that sowing dates, varieties and interaction between sowing dates and varieties had a significant effect on plant height. The tallest plants of 261 $\mathrm{cm}$ were recorded in V3 (SB-989) followed by V8 (AZAM) and V2 (CS-200), while the smallest plants $(196 \mathrm{~cm})$ were recorded in $\mathrm{V} 9$ (BABAR). This was due to the fact that plant height is a genetically controlled factor so the height of different varieties does not remain equal. These results are in accordance with the results of Ali (1994) who also reported a difference of plant height in different maize varieties. Similarly, tallest plants of 259 $\mathrm{cm}$ were recorded in SD1 (June $1^{\text {st }}$ ) followed by SD2 (10 June) and SD5 (13 July) while the smallest plants of $200 \mathrm{~cm}$ were recorded in SD3 (22 June). The interaction effect of variety $x$ 
sowing date on plant height was significant, indicating that varieties differed under different sowing dates (Figure 1).

Table 1: Plant height of different maize varieties as affected by different sowing dates and varieties.

\begin{tabular}{|l|l|l|l|l|l|l|}
\hline Varieties & SD 1 & SD 2 & SD 3 & SD 4 & SD 5 & Mean \\
\hline V 1 & 252 & 207 & 223 & 223 & 221 & $225^{\mathrm{c}}$ \\
\hline V 2 & 272 & 224 & 200 & 234 & 221 & $230^{\mathrm{bc}}$ \\
\hline V 3 & 284 & 280 & 270 & 250 & 221 & $261^{\mathrm{a}}$ \\
\hline V 4 & 272 & 212 & 192 & 170 & 212 & $212^{\mathrm{d}}$ \\
\hline V 5 & 279 & 202 & 150 & 210 & 212 & $211^{\mathrm{d}}$ \\
\hline V 6 & 272 & 230 & 212 & 150 & 212 & $215^{\mathrm{d}}$ \\
\hline V 7 & 223 & 170 & 214 & 208 & 221 & $207^{\mathrm{d}}$ \\
\hline V 8 & 272 & 250 & 192 & 240 & 222 & $236^{\mathrm{b}}$ \\
\hline V 9 & 194 & 220 & 160 & 190 & 212 & $196^{\mathrm{e}}$ \\
\hline V 10 & 272 & 240 & 180 & 231 & 220 & $229^{\mathrm{bc}}$ \\
\hline Mean & $259^{\mathrm{a}}$ & $224^{\mathrm{b}}$ & $200^{\mathrm{e}}$ & $211^{\mathrm{d}}$ & $218^{\mathrm{c}}$ & 222 \\
\hline Mean & & & &
\end{tabular}

Mean followed by different letters in each category are significantly different using LSD at $\mathrm{P} \leq 0.05$

The tallest plant of $284 \mathrm{~cm}$ was recorded in V3 (SB-989) when sown on SD1 (1 June) followed by V3 (SB-989) and V5 (W-888) sown on SD2 (10 June) and SD1 (June $1^{\text {st }}$ ) respectively, while the smallest plant of $151 \mathrm{~cm}$ was recorded in V6 (JALAL) when sown on SD4 (3 July). The results are in the conformity of Beirigi et al. who reported that positive effect of sowing dates on plant height when sowing was delayed to June [41-44].

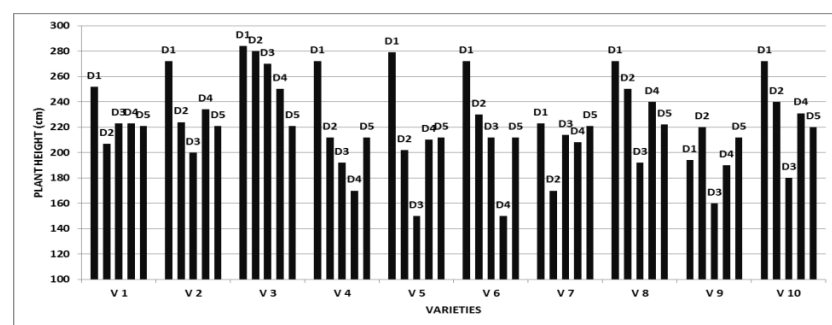

Figure 1: Interaction effect of varieties (V) and sowing dates (D) on plant height $(\mathrm{cm})$ of different maize varieties.

\section{Biological yield}

Data presented in (Table 3) showed that biological yield ( $\mathrm{kg}$ $\mathrm{ha}^{-1}$ ) was significantly affected by sowing dates and varieties as well as by interaction between the two. Significant differences were noted among the maize varieties in biological yield. The maximum biological yield of $32839 \mathrm{~kg} \mathrm{ha}^{-1}$ was recorded in V8 (AZAM) followed by V3 (SB-989) and V6 (JALAL), while the minimum biological yield of $20644 \mathrm{~kg} \mathrm{ha}^{-1}$ was recorded in V4 (IQBAL). Similarly, the maximum biological yield of $35874 \mathrm{~kg} \mathrm{ha}^{-1}$ was recorded from SD1 (1 June) followed by SD2 (10 June) and
SD5 (13 July), while the minimum biological yield of $21487 \mathrm{~kg}$ $\mathrm{ha}^{-1}$ was recorded from SD3 (22 June) [6]. The interaction effect of variety $x$ sowing date on biological yield was significant, indicating that varieties differed under different sowing dates (Figure 2). Maximum biological yield of $46668 \mathrm{~kg} \mathrm{ha}^{-1}$ was recorded in V6 (JALAL) when sown on SD1 (1 June) followed by V8 (AZAM) sown on SD2 (10 June) and SD1 (1 June) respectively, while minimum biological yield of $10000 \mathrm{~kg} \mathrm{ha}^{-1}$ was recorded in V4 (IQBAL) when sown on SD4 ( $3^{\text {rd }}$ July). Our results are in agreement with Azad et al. [6] They reported that on the first and Second sowing dates (early sowing) due to larger growth period, the appropriate use of environmental factors affecting growth, increase of the dry matter in various parts of plants, biological yield enhanced.

Table 2: Biological yield $\left(\mathrm{kg} \mathrm{ha}^{-1}\right)$ of different maize varieties as affected by different sowing dates and varieties.

\begin{tabular}{|l|c|c|c|c|c|c|}
\hline $\begin{array}{l}\text { Varietie } \\
\text { S }\end{array}$ & SD 1 & SD 2 & SD 3 & SD 4 & SD 5 & mean \\
\hline V 1 & 33334 & 27667 & 30389 & 30389 & 26723 & $29701^{\text {c }}$ \\
\hline V 2 & 30001 & 26667 & 26667 & 27701 & 26367 & $27481^{\text {d }}$ \\
\hline V 3 & 37556 & 38223 & 31667 & 20001 & 26090 & $30707^{\text {b }}$ \\
\hline V 4 & 33334 & 19367 & 15001 & 10001 & 25512 & $20643^{9}$ \\
\hline V 5 & 40001 & 21667 & 10001 & 18334 & 26678 & $23336^{f}$ \\
\hline V 6 & 46667 & 33334 & 31034 & 13334 & 27023 & $30279^{\text {bc }}$ \\
\hline V 7 & 40000 & 16667 & 23445 & 26667 & 27234 & $26803^{\text {d }}$ \\
\hline V 8 & 40112 & 43334 & 20001 & 34367 & 26378 & $32839^{a}$ \\
\hline V 9 & 20945 & 28334 & 13334 & 16723 & 24001 & $20668^{9}$ \\
\hline V 10 & 36778 & 23112 & 13334 & 24367 & 25034 & $24525^{\mathrm{e}}$ \\
\hline Mean & $\begin{array}{l}35873 \\
\text { a }\end{array}$ & $27837^{\mathrm{b}}$ & $21488^{\mathrm{e}}$ & $22189^{\mathrm{d}}$ & 26104 & 26698 \\
\hline $\begin{array}{l}\text { Mean followed by different letters in each category are significantly different } \\
\text { using LSD at P } 0.05\end{array}$ & & & \\
\hline
\end{tabular}

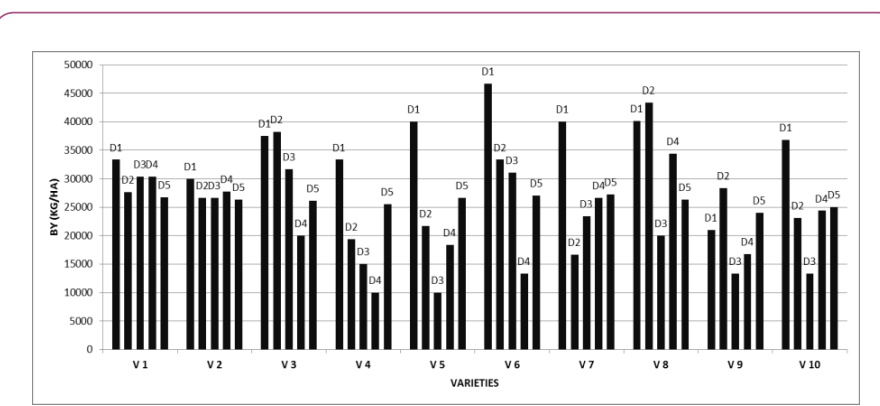

Figure 2: Interaction effect of varieties $(\mathrm{V})$ and sowing dates (D) biological yield $\left(\mathrm{kg} \mathrm{ha}^{-1}\right)$ of different maize varieties.

\section{Grain yield}

Data presented in (Table 3 ) showed that grain yield $\left(\mathrm{kg} \mathrm{ha}^{-1}\right)$ was significantly affected by sowing dates and varieties as well as by interaction between the two. Significant differences were 
noted among the maize varieties in grain yield. Maximum grain yield of $4666 \mathrm{~kg} \mathrm{ha}^{-1}$ was recorded inV7 (SB-909) followed by V6 (JALAL) and V10 (SB-292), while minimum grain yield of $3382 \mathrm{~kg}$ $\mathrm{ha}^{-1}$ was recorded in $\mathrm{V} 9$ (BABAR). Variation in yield revealed a diverse genetic background of varieties tested in this study. These results are in line with those of McCutcheon et al. who reported significant differences among maize cultivars for grain yield. Similarly, maximum grain yield of $4937 \mathrm{~kg} \mathrm{ha}^{-1}$ was recorded from SD (1 June) followed by SD5 (13 July) and SD2 (10 June), while minimum grain yield of $3209 \mathrm{~kg} \mathrm{ha}^{-1}$ was recorded from SD3 (June 22). The interaction effect of variety $\times$ sowing date on grain yield was significant, indicating that varieties differed under different sowing dates (Figure 3). Maximum grain yield of $5861 \mathrm{~kg} \mathrm{ha}^{-1}$ was recorded in V7 (SB-909) when sown on SD4 (3 July) followed by V1 (CS-220), while minimum grain yield of $\mathrm{kg} \mathrm{ha}^{-1}$ was recorded in V8 (AZAM) when sown on SD3 (June 22). Ali et al. also found a significant interaction effect of sowing dates and varieties for grain yield [3]. These results are similar to the reports of Hardman et al. Namaka et al. and Kamara et al. who had noted a considerable reduction in yield and yield components when sowing was delayed [18-22].

Table 3: Grain yield $\left(\mathrm{kg} \mathrm{ha}^{-1}\right)$ of different maize varieties as affected by different sowing dates and varieties.

\begin{tabular}{|c|c|c|c|c|c|c|}
\hline Varieties & SD 1 & SD 2 & SD 3 & SD 4 & SD 5 & Mean \\
\hline V 1 & 5691 & 2649 & 2756 & 4328 & 3955 & $3876^{c}$ \\
\hline V 2 & 5215 & 2215 & 2246 & 4418 & 4344 & $3688^{d}$ \\
\hline V 3 & 5153 & 4600 & 4450 & 1853 & 3853 & $3982^{c}$ \\
\hline V 4 & 4812 & 4238 & 3011 & 3063 & 4238 & $3873^{c}$ \\
\hline$\vee 5$ & 5461 & 4479 & 4864 & 3227 & 3530 & $4312^{b}$ \\
\hline V 6 & 4555 & 4156 & 4671 & 4420 & 4175 & $4396^{b}$ \\
\hline$\vee 7$ & 4148 & 4724 & 4149 & 5861 & 4446 & $4666^{a}$ \\
\hline V 8 & 5242 & 4721 & 1138 & 2823 & 4120 & $3609^{d}$ \\
\hline V 9 & 4346 & 4284 & 1353 & 2854 & 4077 & $3383^{e}$ \\
\hline$\vee 10$ & 4744 & 4953 & 3454 & 4124 & 4339 & $4323^{b}$ \\
\hline Mean & $4937^{a}$ & $4102^{b}$ & $3209^{d}$ & $\begin{array}{l}3697 \\
c\end{array}$ & $4108^{b}$ & 4011 \\
\hline
\end{tabular}

Mean followed by different letters in each category are significantly different using LSD at $P \leq 0.05$

\section{Conclusion}

From the results, it was concluded that 1st June sowing time of maize showed best results compared to other sowing times. SB-909 performs better among other varieties for grain yield and yield components.

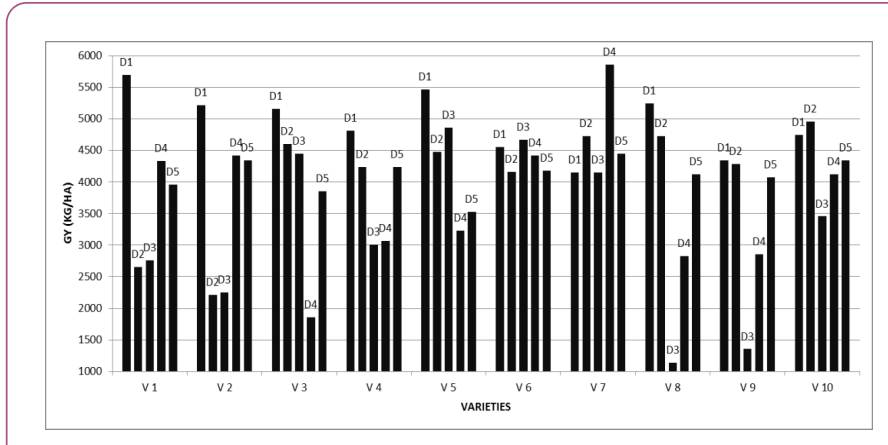

Figure 3: Interaction effect of varieties (V) and sowing dates (D) grain yield $\left(\mathrm{kg} \mathrm{ha}^{-1}\right)$ of different maize varieties.

\section{References}

1. Ahmad S, Khan M, Ikram MZ (1990) Soil and water conservation and integrated land use in Pothwar, Pakistan. In: Soil PhysicsApplication under stress environments. Barani Agricultural Research and Development Project (BARD), PARC, Islamabad 301-312.

2. Ahmed A, Munsif F, M Arif, Inamullah, M Nauman (2011) Yield and yield component of maize as affected by sowing dates and sowing methods. FUUAST J Biol 1: 75-80.

3. Ali M, Khan F, Khan I, Ali W, Sara S, et al. (2018) Soil and water conservation practices in district Swabi, KP, Pakistan. Adv Crop Sci Tech 6: 1-9.

4. Amjadian M, Farshadfar M, Gholoipoor M, Shirvani H (2013) The effects of planting date on the yield and yield components of corn (Zea mays L.) cultivar, single cross 704. Agric Sci Dev 4: 38-41.

5. Saseendran SA, Ma L, Nielsen DC, Vigil MF, Ahuja LR (2005) Simulating planting date effects on corn production using RZWQM and CERES-Maize models. Agronomy J 17: 58-71.

6. Azadbakht A, Azadbakht G, Nasrollahi H, Bitarafan Z (2012) Evaluation of different planting dates effect on three maize hybrids in Koohdasht region of Iran. J Surf Eng Mater Adv Technol 2: 34-38.

7. Beiragi MA, SK Khorasani, SH Shojaei, M Dadresan, K Mostafavi, et al. (2011) Study on planting dates on growth and yield of 18 corn hybrids (Zea mays L.) W Exp Agr 1: 110-120.

8. Blake GR, Hartge KH (1986) Particle density. American Society of Agronomy.

9. Bouyoucos GJ (1962) Hydrometer method improved for making particle-size analysis of soils. Agron J 53 464-465.

10. Bremner JM, Mulvaney CS (1982) Nitrogen-total. Methods of soil analysis. Part 2. Chemical and microbiological properties methods of soil. American Society of Agronomy, Soil Science Society of America 595-624.

11. Buririo M, Bhutto TA, Gandahi AW, Kumbhar IA, Shar MU (2015) Effect of sowing dates on growth, yield and grain quality of hybrid maize. J Basic Appl Sci 11: 553-558.

12. Cakir R (2004) Effect of water stress at different development stages on vegetative and reproductive growth of corn. Field Crops Research 89: 1-16. 
13. Casini P (2012) Maize production as affected by sowing date, plant density and row spacing in the Bolivian Amazon. J Agri Environ Int Dev 106: 75-84.

14. Chaudhry QZ, Rasul G (2004) Agro-climatic classification of Pakistan. Science Vision 9: 59-66.

15. Pramanik P, Chakrabarti B, Bhatia A, Singh SD, Mridha N, et al. (2018) Effect of elevated carbon dioxide on soil hydrothermal regimes and growth of maize crop (Zea mays L.) in semi-arid tropics of Indo-Gangetic Plains. Environ Monit Assess 190: 661.

16. Grant FR, Jackson BS, Kiniry JR, Arkin GF (1989) Water deficit timing effects on yield components in maize. Agron J 81: 61-65.

17. Hardman L, Gunsolus JL (2002) Corn growth and development and management information for replant decisions. Minnesota Extension Service, University of Minnesota 1-12.

18. Heisey PW, Edmeades GO (1999) Maize production in droughtstressed environments: Technical options and research resource allocation. CIMMYT World Maize Facts and Trends 1-72.

19. http://travelguide.pk/gallerycitiesfatamohmandagency.php

20. Jin YH, Zhou DW, Qin LJ (2012) Sowing date of corn in semiarid region in adapting to climate change. J Appl Ecol 23: 2795-2802.

21. Kamara AY, Ekeleme F, Chikoye D, Omoigui LO (2009) Planting date and cultivar effects on grain yield in Dryland corn production. Agron J 101: 91-98.

22. Kgasago H (2006) Effect of planting dates and densities on yield and yield components of short and ultra-short growth period of maize. M Inst Agri Agron 1-120.

23. Khan N, M Qasim, F Ahmed, F Naz, R Khan, et al. (2002) Effect of sowing dates on yield of maize under agro-climatic condition of Kaghan valley. Asian J PIt Sci 1: 146-147.

24. Gaile $Z$ (2012) Maize response to sowing timing under agroclimatic conditions of Lativa. Zemdirbyste Agri 99: 31-40.

25. Maga TJ, Vange T, Ogwuche TO (2015) The influence of sowing dates on the growth and yield of two maize varieties cultivated under Southern Guinea Savannah Agro-ecological zone. Amer J Exp Agri 5: 200-208.

26. Miller JP, Toor G (2007) Influence of sowing date and hybrid on maize emergence. Agronomy New Zealand 37: 15-22.

27. MINFA (2011) Ministry of Food and Agriculture, Agriculture Statistics of Pakistan. Govt. of Pak, Economic Wing, Islamabad.

28. Muchow RC (1989) Comparative productivity of maize, sorghum and pearl millet in a semi-arid tropical environment II. Effects of water deficits. Field Crop Res 20: 207-219.

29. Mukhtiar A, Waqar A, Khalil MQ, Tariq M, Muhammad S, et al. (2018) Evaluating the potential organic manure for improving wheat yield and quality under agro-climatic conditions of Pakistan. Adv Crop Sci Tech 6: 1-4.

30. Naheed G, Mahmood A (2009) Water Requirements for wheat crop in Pakistan. Pak J Meteorol 6: 89-97.
31. Namakka A, Abubakar IU, Sadik IA, Sharifai Al, Hassas AH (2008) Effect of sowing date and nitrogen level on yield and yield components of two extra early maize varieties (Zea mays L.) in Sudan savanna of Nigeria· J Agric Biol Sci 3: 1-5.

32. Nelson DW, Sommers LE (1982) Total carbon, organic carbon and organic matter. In: A.L. Page (eds) Methods of soil analysis Parts 2. 2nd Ed. AM. Soc Agron Inc Madison WI USA 539-579.

33. Parent $B$, Leclere $M$, Lacube $S$, Semenov MA, Welcker $C$, et al. (2018) Maize yields over Europe may increase in spite of climate change, with an appropriate use of the genetic variability of flowering time. Proc Natl Acad Sci USA 115: 10642-10647.

34. Peykarestan B, Seify M (2012) Impact of sowing dates on growth and yield attributes of popcorn grown under different densities. Int Res J App Basic Sci 3: 85-91.

35. Qureshi AS, Qadir M, Heydari N, Turral H, Javadi A (2007) A review of management strategies for salt-prone land and water resources in Iran. International water management Institute. Colombo, Sri Lanka.

36. Ramankutty N, Foley JA, Norman J, McSweeney K (2002) The global distribution of cultivable lands: Current patterns and sensitivity to possible climate change. Glob Ecol Biogeogr 13: 377-392.

37. Richard LA (1954) Diagnosis and improvement of saline and alkali soils. United State Department of Agriculture handbook 60 Washington DC.

38. Saberi A (2014) The effect of sowing date on yield of silage corn hybrids. J Adv Bot Zool 1: 2348-7313.

39. Shah SR (2007) Effect of seed priming on yield and yield components of maize. Dept. Argon KP Agric Univ Peshawar, Pakistan 1-73.

40. Shimono H, Miyazaki H, Shinjo H, Kanno H, Sakurali T (2008) Effect of sowing dates on maize productivity in Southern Zambia in the growing season. Research Institute for Humanity and Nature 1-187.

41. Soltanpour PN, Schwab AP (1977) A new soil test for simultaneous extraction of macro and micronutrients in alkaline soil. Commun Soil Sci Plant Anal 8: 195-207.

42. Thomas GW (1996) Soil pH and soil acidity. Methods of soil analysis. Part 3. Chemical Methods, American Society of Agronomy 475-490.

43. Tolera A, Berg T, Sundstol F (1999) The effect of variety on maize grain and crop residues yield and nutritive value of the stover. $J$ Animal feed Sci Tech 79: 165-177.

44. Wilson DR, Johnstone JV, Salinger MJ (1994) Maize production potential and climatic risk in the South Island of New Zealand, N. Z. J Crop Hortic Sci 22: 321-334. 